\title{
Agroindustry Waste as Source of Nutrients for Soybean Production and Influence on Soil Microbiology
}

\author{
João Carlos Gonçalves ${ }^{1}$, Francielli Gasparotto ${ }^{2,3}$, Márcia Aparecida Andreazzi ${ }^{2,3}$, Edison Schmidt Filho ${ }^{2,3}$, \\ Cleiltan Novais da Silva ${ }^{2}$, Natália Caetano Vasques ${ }^{1}$, Bárbara Maria Lustri ${ }^{1}$
}

${ }^{1}$ Centro Universitário de Maringá - Unicesumar, 87050-900, Maringá-PR, Brazil

${ }^{2}$ Programa de Pós-graduação em Tecnologias Limpas, Centro Universitário de Maringá - Unicesumar, Av. Guedner, 1610, 87050-900, Maringá-PR, Brazil

${ }^{3}$ Instituto Cesumar de Ciência, Tecnologia e Inovação - ICETI, Maringá, PR, Brazil

Correspondence Author: Francielli Gasparotto, Programa de Pós-graduação em Tecnologias Limpas, Centro Universitário de Maringá - Unicesumar, Av. Guedner, 1610, 87050-900, Maringá-PR, Brazil

Instituto Cesumar de Ciência, Tecnologia e Inovação - ICETI, Maringá, PR, Brazil.

E-mail:- francielli.gasparotto@unicesumar.edu.br

Received date: 15 September 2019, Accepted date: 12 December 2019, Online date: 31 December 2019

Copyright: ( 2019 João Carlos Gonçalves et al, This is an open-access article distributed under the terms of the Creative Commons Attribution License, which permits unrestricted use, distribution, and reproduction in any medium, provided the original author and source are credited.

\begin{abstract}
The use of agroindustrial and livestock residues as fertilizers for crops is a promising alternative aiming at environmental and economic sustainability. Residues can be obtained through various agricultural and agroindustrial activities such as sugar cane processing and animal production such as poultry farming and are commonly used on different vegetables. Therefore, the objective of this work was to evaluate the influence of the application of chicken litter and filter cake, associated or not to mineral fertilization, in the soil microbial population and in the development of soybean plants. Organic fertilization (cane filter cake - SFC, chicken bed - PL) and chemical fertilization (nitrogen - phosphorus - potassium - NPK - 04 - 30 - 10) were applied. The treatments were: T1-PL (5 ton ha-1), T2-PL (5 ton ha-1) + NPK (139 kg ha -1), T3-SFC (25 ton ha -1), T4- 5 ton ha-1) + NPK (257 kg ha-1), T5 - NPK (139 kg ha-1) and T6 - control (without fertilizer application). The number of colonies of fungi, bacteria and actinomycetes was evaluated. The development of the soybean crop was analyzed by counting the number of emerged seedlings, number of root nodules and yield of grains. Statistical differences $(p<0.05)$ were observed in the population of actinomycetes submitted to T2, T4 and T6 treatments. The other factors presented similar results for all treatments. Therefore, it is suggested the possibility of using filter cake and chicken bed as a source of nutrients for soybean cultivation, since the application improves soil properties and does not cause negative changes in the microbial population.
\end{abstract}

Keywords: Glycine max. Fertilization. Microbiota. Sustainable production

\section{INTRODUCTION}

Soybean [Glycine $\max (\mathrm{L}$.) Merrill] is considered one of the main agricultural commodities. The United States led production, in the year 2018, with 119.518 million tons, followed by Brazil with 116.996 million tons (USDA, 2018). Due to the increasing demand, it is necessary to maximize the productivity of the soybean crop (Manteli et al., 2019).

The low fertility of agricultural soils and the high costs of fertilizers are limiting factors for higher yields (Castro et al., 2006; Pimentel, 2009). Related to this, the harmful effects of chemical fertilization on the environment evidences the need for the search for sustainable agriculture, which maintains the fertilization of the soil using available resources in the agroindustry chain. The combined application of chemical and organic fertilizer sources, often referred to as integrated nutrient management, is recognized to increase crop productivity sustainably (Mahajan et al., 2008).

Therefore, agroindustries wastes, such as poultry litter and filter cake, play an essential role in the availability of nutrients to crops, because these materials are composed of elements that contribute to the growth and development of the plants, besides, it contains large amounts of organic matter, contributing to improving soil characteristics (Fravet et al., 2010; Szogi et al., 2010; Santana et al., 2012).

The use of the filter cake contributes to the improvement of the biological activity of the soil, providing nutrients to the microorganisms, which through the mineralization release nutrients gradually, culminating in high utilization by the plants (Nunes Junior, 2005; Santana et al., 2012; Gonzáles et al., 2014). 
The poultry litter containing high levels of N, P, and K is characterized as a potent nutritional agent (De Paula Junior, 2014). Studies were carried out to demonstrate the feasibility of applying the waste in areas planted with soybeans (Adeli et al., 2005), maize (Boateng et al., 2006) and cotton (Adeli et al., 2007). However, it is important to emphasize the need not only to evaluate the nutritional contribution of fertilizer application to crops but also the effect of fertilizer application on the population of microorganisms present in the soil.

Microorganisms are essential in the development of crops because they are responsible for the release of enzymes that contribute to the degradation of organic matter and subsequent mineralization of nutrients (Moreira and Siqueira, 2012).

Besides, in soybean, microorganisms are responsible for nodulation, a process that provides nitrogen for the crop (Malavolta, 2006). However, moisture retention by the soil favored by the application of organic waste directly influences the modulation. Thus, the availability of water in the soil is closely related to nodulation (Ruviaro et al., 2011) and, consequently, biological nitrogen fixation.

Therefore, the objective of this work was to evaluate the influence of the application of poultry litter and filter cake, associated or not to mineral fertilization, on the soil microbial population and soybean development.

\section{MATERIALS AND METHODS}

The experiment was conducted in the municipality of Maringá in Brazil, on the experimental farm $\left(23^{\circ} 34^{\prime} 18^{\prime \prime} \mathrm{N} ; 51^{\circ} 87^{\prime} 52^{\prime \prime}\right.$ $\mathrm{W} ; 515 \mathrm{~m}$ above sea level). The studied soil was the Eutrophic Red Latosol (EMBRAPA, 2007). According to the climate classification of Koppen, the region is Cfa, average annual precipitation of $1276 \mathrm{~mm}$ and an average temperature of $23^{\circ} \mathrm{C}$.

Samples were taken from soil depth of 0 to $20 \mathrm{~cm}$ and the chemical and physical properties were determined before the implantation of the experiment, whose results are presented in Table 1. The analyzes were carried out at the Maringa Rural Laboratory.

Table1. The physical and chemical properties of the soil of the experimental area before the implementation of the test.

\begin{tabular}{|c|c|}
\hline Property & Index \\
\hline Phosphorus $\left(\mathrm{mg} / \mathrm{dm}^{3}\right)$ & 11.21 \\
\hline Organic Carbon $\left(\mathrm{g} / \mathrm{dm}^{3}\right)$ & 14.34 \\
\hline $\mathrm{pH}$ & 4.85 \\
\hline Aluminum $\left(\mathrm{cmolc} / \mathrm{dm}^{3}\right)$ & 0.05 \\
\hline Potential acidity $\left(\mathrm{cmolc} / \mathrm{dm}^{3}\right)$ & 6.04 \\
\hline Calcium + Magnesium $\left(\mathrm{cmolc}^{3} \mathrm{dm}^{3}\right)$ & 12.57 \\
\hline Calcium $\left(\mathrm{cmolc} / \mathrm{dm}^{3}\right)$ & 9.75 \\
\hline Magnesium $\left(\mathrm{cmolc} / \mathrm{dm}^{3}\right)$ & 2.82 \\
\hline Potassium $\left(\mathrm{cmolc} / \mathrm{dm}^{3}\right)$ & 0.46 \\
\hline Sum of Bases $\left(\mathrm{cmolc}^{3} \mathrm{dm}^{3}\right)$ & 13.03 \\
\hline Cation exchange capacity $\left(\mathrm{cmolc}^{3} \mathrm{dm}^{3}\right)$ & 17.70 \\
\hline Base Saturation $(\%)$ & 68.30 \\
\hline Aluminum saturation $(\%)$ & 0.0 \\
\hline Copper $\left(\mathrm{mg} / \mathrm{dm}^{3}\right)$ & 43.70 \\
\hline Iron $\left(\mathrm{mg} / \mathrm{dm}^{3}\right)$ & 46.53 \\
\hline Manganese $\left(\mathrm{mg}^{3} \mathrm{dm}^{3}\right)$ & 109.50 \\
\hline Zinc $\left(\mathrm{mg} / \mathrm{dm}^{3}\right)$ & 34.28 \\
\hline
\end{tabular}

The Experiment was set up as a randomized complete block design with 6 treatments and 4 replications. The size of each plot was $4 \times 5 \mathrm{~m}$. Soybean cultivar Coodetec 2644 IPRO was planted in at $0.40 \mathrm{~m}$ row spacing. Organic fertilizer (sugarcane filter cake SFC; poultry litter - PL) and chemical fertilization (nitrogen-phosphorus-potassium - NPK - 04-30-10) were applied. The treatments were: T1 - PL $\left(5\right.$ ton ha $\left.{ }^{-1}\right)$, T2 - PL $\left(5\right.$ ton ha $\left.^{-1}\right)+$ NPK $\left(139 \mathrm{~kg} \mathrm{ha}^{-1}\right)$, T3 - SFC $\left(25\right.$ ton ha $\left.^{-1}\right)$, T4 - SFC $\left(5\right.$ ton ha $\left.{ }^{-1}\right)+$ NPK (257 kg ha $\left.{ }^{-1}\right)$, T5 - NPK (139 kg ha-1) e T6 - control (without application).

The filter cake was obtained in a sugar and ethanol plant, and the poultry litter used was made from six lots, both of which were collected in the region of Maringa. Samples of the two materials were sent for physical-chemical analysis (Table 2). Mineral fertilization was carried out in the subsoil in soybean sowing. The application of organic wastes was carried out manually.

Table 2. Percentage of moisture $(\mathrm{M})$, organic matter $(\mathrm{OM})$, carbon/nitrogen ratio $(\mathrm{C} / \mathrm{N})$, $\mathrm{pH}$ and concentration of nitrogen $(\mathrm{N})$, phosphorus $(\mathrm{P})$, potassium $(\mathrm{K})$, calcium $(\mathrm{Ca})$, magnesium $(\mathrm{Mg})$ and carbon $(\mathrm{C})$ of the filter cake and poultry litter used in the experiment.

\begin{tabular}{|c|c|c|c|c|c|c|c|c|c|c|}
\hline \multirow{2}{*}{$\begin{array}{c}\text { Agroindustry } \\
\text { waste }\end{array}$} & \multicolumn{10}{|c|}{ Property } \\
\cline { 2 - 12 } & $\mathrm{M}$ & $\mathrm{OM}$ & $\mathrm{C} / \mathrm{N}$ & $\mathrm{pH}$ & $\mathrm{N}$ & $\mathrm{P}$ & $\mathrm{K}$ & $\mathrm{Ca}$ & $\mathrm{Mg}$ & $\mathrm{C}$ \\
\cline { 2 - 12 } & $\%$ & $\%$ & & & \multicolumn{7}{|c|}{$\mathrm{g} \mathrm{kg}^{-1}$} & \multicolumn{7}{c|}{} \\
\hline Filter cake & 71.0 & 69.76 & 28.3 & 6.63 & 14.33 & 16.9 & 1.48 & 23.07 & 3.4 & 405.6 \\
\hline Poultry litter & 29.3 & 48.64 & 8.0 & 7.80 & 32.50 & 25.5 & 41.10 & 22.50 & 16.2 & - \\
\hline
\end{tabular}


The variables measured in the experiments were: germination, number of root nodules, yield and microbial diversity.

Seed germination: The percentage of germinated seeds was obtained by counting all emerged seedlings in each plot 15 days after sowing.

Numbers of nodules: At the physiological stage R1 (beginning of flowering), ten plants were randomly collected in each plot, computing all the nodules present in the root system of each plant.

Productivity: To evaluate soybean yield, $2 \mathrm{~m}^{2}$ were collected in the central area of each plot. The soybean was harvested manually, threshed and weighed using a precision balance. The determination of soybean grain yield was measured in $\mathrm{kg}^{-1}$.

Microbial diversity: Soil samples were collected at 0-10 $\mathrm{cm}$ depth. From each composite sample, a 10-gram sub-sample was withdrawn, suspended in $90 \mathrm{~mL}$ of saline, and stirred for 30 minutes. Serial dilutions were performed and $0.1 \mathrm{ml}$ aliquots of the $10^{-3}$ concentration were plated separately in Petri dishes containing Martin and casein medium, selective for fungi and actinomycetes, respectively. Dilutions of $10^{-5}$ and $10^{-6}$ were plated in nutrient agar medium for bacteria. Cultures were incubated in the dark at $28^{\circ} \mathrm{C}$ for five days for fungi and actinomycetes and three days for bacteria. The number of colony-forming units (CFU) was counted and calculated per gram of soil (Santos et al., 2009).

Statistical analysis: Data were submitted to analysis of variance (ANOVA) using the SASM-Agri software (Canteri et al., 2001) and the means compared by the Scott Knott test at a 5\% significance level.

\section{RESULTS AND DISCUSSION}

Germination was evaluated at 15 days after sowing and treatments did not differ ( $p>0.05$ ) (Table 3). The result may have been influenced by the straw existing in the soil, due to previous harvests (soybean, maize and wheat). Probably, no-till increased the water retention capacity, favoring the germination and emergence of soybean seedlings.

Table 3. Values referring to germination (\%), nodules (nodule number in 10 plants) and grain yield (Kg/ha) of the soybean crop submitted to different treatments.

\begin{tabular}{|c|c|c|c|}
\hline Treatments ${ }^{\mathbf{1}}$ & Germination (\%) & $\begin{array}{c}\text { Nodule number } \\
\left(\text { number } \text { plant }^{-1} \text { ) }\right.\end{array}$ & Grain yield (Kg/ha) $^{\text {(\%) }}$ \\
\hline T1 & $86.37 \mathrm{a}$ & $328.75 \mathrm{a}$ & $4.480 \mathrm{a}$ \\
\hline T2 & $84.85 \mathrm{a}$ & $338.50 \mathrm{a}$ & $3.990 \mathrm{a}$ \\
\hline T3 & $82.76 \mathrm{a}$ & $341.75 \mathrm{a}$ & $4.860 \mathrm{a}$ \\
\hline T4 & $84.47 \mathrm{a}$ & $441.00 \mathrm{a}$ & $4.380 \mathrm{a}$ \\
\hline T5 & $76.14 \mathrm{a}$ & $289.75 \mathrm{a}$ & $4.820 \mathrm{a}$ \\
\hline T6 & $77.46 \mathrm{a}$ & $361.75 \mathrm{a}$ & 5.76 \\
\hline CV $(\%)$ & 3.66 & 9.09 & $\mathrm{~T}$ \\
\hline
\end{tabular}

Treatments = T1-Poultry litter; T2- Poultry litter + mineral fertilization; T3- Filter cake; T4- Filter cake + mineral fertilization; T5 - mineral fertilization; T6- control. * Means followed by the same letters, in the column, do not differ statistically by Scott Knott test $(5 \%)$. CV $=$ coefficient of variation.

The application and maintenance of organic waste in the soil positively influenced seed germination. Magalhães (2017) observed that the use of bovine manure provided the increase of organic carbon, particulate organic carbon, total porosity, macroporosity and stability index of soil aggregates in water, reduction of soil density and soil resistance to the penetration, benefiting the germination.

There were no differences between treatments for the variable nodules in roots (Table 3). No-tillage has a direct influence on the nodulation of soybean plants, according to Ruviaro et al. (2011), nodulation is closely linked to the availability of water in the soil. This factor may have influenced the outcome of this research because the area had a history of the no-tillage system.

The plants, submitted to the different treatments, presented medium nodules varying between 22.9 and 44.1 nodules/plant, in the physiological stage R1. According to Câmara (2000), plants with 10 to 30 nodules between the physiological stages R1 and R2 present sufficient conditions to reach high yields. It was observed that there was no negative influence on the nodulation process of the plants, even for treatments that contained nitrogen fertilization at sowing.

The use of high doses of mineral nitrogen fertilization in soybean sowing interferes negatively in the nodulation process, Moreira and Siqueira (2006) emphasize that the chemical signaling process between soybean plants and diazotrophic bacteria is impaired by the availability of high doses of nitrogen in the soil, resulting in a lower number of nodules.

Reduction of nodulation may lead to reductions in soybean yield, because of the lower the biological fixation, the lower the amount of nitrogen available to the plants. Nitrogen is the element required in greater quantity by soybean (Malavolta, 2006). Therefore, factors favoring the increase of nodulation and consequently the biological fixation of nitrogen culminates in the increase of soybean yield.

Câmara (2014) reports that when soybean is grown under no-till system in the straw, it may occur the need to provide mineral nitrogen to assist in the decomposition of the straw that will be transformed into organic matter, therefore, part of the mineral nitrogen of the soil is immobilized by decomposing microorganisms. 
In these situations, small amounts of nitrogen are applied to improve the balance of the carbon/nitrogen ratio, benefiting the decomposition with lower nitrogen consumption of the soil. This corroborates with the results found in this research because the amount of nitrogen applied was enough to improve the decomposition of the organic material but did not influence the nodulation.

Santos et al. (2005) consider that in the first year of cultivation with organic fertilization the productivity is generally lower when compared to mineral fertilization. However, a contrary result was found in this study because no statistical differences were observed between treatments ( $p>0.05$ ) in productivity (Table 3 ).

In general, when using organic sources for fertilization, the advantages are not limited only to the application crop, because there is a residual effect in subsequent years (Ghoshet et al., 2009 and Ribeiro et al., 2009). Therefore, it is expected that the addition of filter cake and poultry litter under the conditions of this experiment will provide improvements in soil characteristics after continued use.

In the present study, treatments formulated with organic waste did not negatively influence germination, nodulation and productivity. Santana et al. (2012) observed that the application of the filter cake, in addition to the increase of nutrients, improved the physical and biological structure of the soil. Similar results were found by Costa et al. (2009), evaluating the application of the poultry litter in the recovery of Red Latosol. These results suggest the disposal of waste in the soil, act in providing nutrients and contribute to the maintenance of soil integrity.

The results related to the number of fungal colonies forming units of the different treatments were not significant ( $\mathrm{p}>0.05$ ) (Figure 1). This fact can be justified by the moisture maintained in the soil by no-till straw. The microbial population increases as the soil moisture content increases (Rodrigues et al., 2011), corroborating with what was observed in this study.

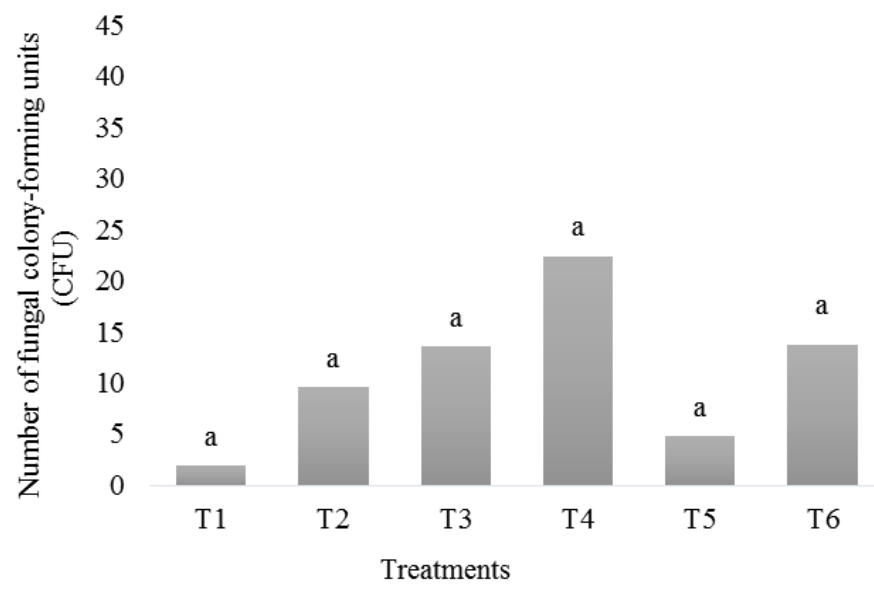

Figure 1. A number of Colony Forming Units (CFU) of fungi in soil.

Treatments = T1-Poultry litter; T2- Poultry litter+ mineral fertilization; T3- Filter cake; T4- Filter cake+mineral fertilization; T5 mineral fertilization; T6- control. *Means followed by the same letter between the columns are not significantly different at $(\mathrm{P}>$ $0.05)$ by the Scott Knott test.

Differences between treatments in the number of Colony Forming Units (CFUs) of bacteria ( $\mathrm{p}>0.05)$ were not observed. The low variation in the bacterial population between treatments reflects the role of these microorganisms in the decomposition of organic waste since they are responsible for the decomposition of less complex materials, such as glucose, released into the soil after cellulose degradation process (Moreira and Siqueira, 2006).

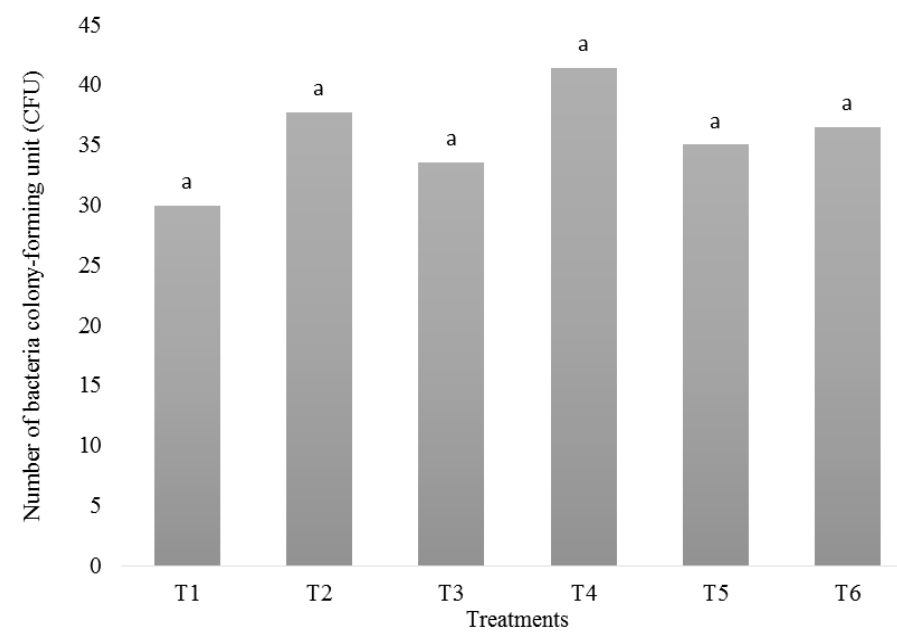

Figure 2. A number of Colony Forming Units (CFU) of bacteria in the soil. 
Treatments = T1-Poultry litter; T2- Poultry litter+ mineral fertilization; T3- Filter cake; T4- Filter cake+mineral fertilization; T5 mineral fertilization; T6- control. *Means followed by the same letter between the columns are not significantly different at $(\mathrm{P}>$ $0.05)$ by the Scott Knott test.

Statistical differences ( $>00.05)$ were observed among treatments in the actinomycete population. in which higher numbers of CFUs were verified in T2, T4 and T6, it is highlighted that the first two were derived from the formulation of mineral fertilization together with organic (Figure 3).

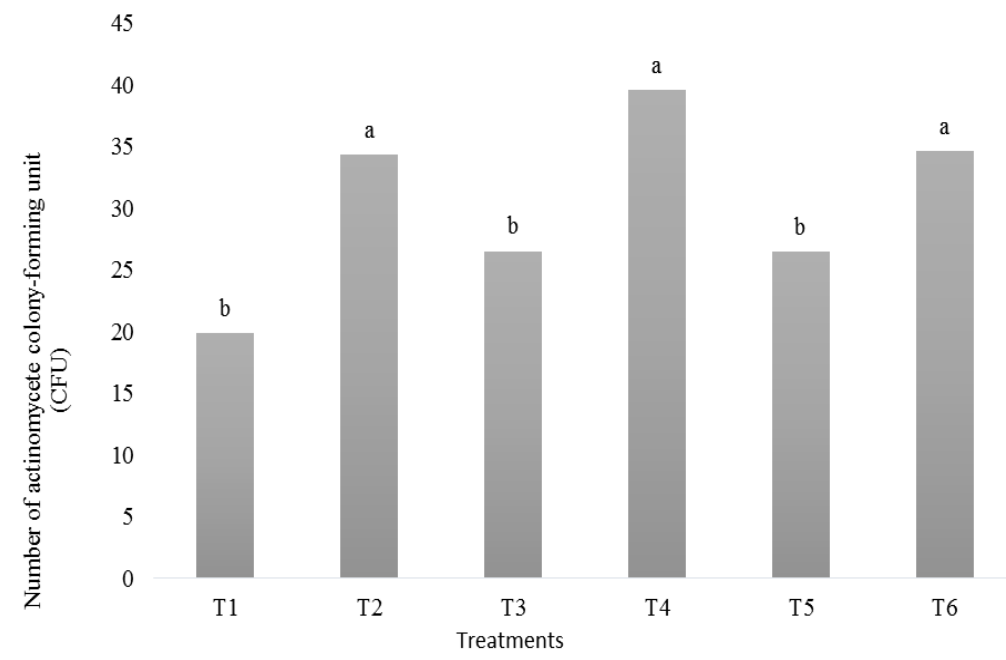

Figure 3. A number of Colony Forming Units (CFU) of actinomycete in soil.

Treatments = T1-Poultry litter; T2- Poultry litter+ mineral fertilization; T3- Filter cake; T4- Filter cake+mineral fertilization; T5 mineral fertilization; T6- control. *Means followed by the same letter between the columns are not significantly different at $(\mathrm{P}>$ $0.05)$ by the Scott Knott test.

The population of actinomycetes was smaller T1, T3 and T5 treatments, probably the population was increased at the beginning of the experiment, and after degrading the majority of the material available in the soil the population decreased. Highlight that the soil samples collected for the analysis of the microorganisms were performed 4 months after the implant of the experiment.

Actinomycetes play an important role in the degradation of complex macromolecules of the soil (Moreira and Siqueira, 2006), as the waste used in this experiment. According to Neves et al. (1983) by decreasing the competitive stress among microorganisms by the compounds easier to assimilate, the population of actinomycetes increases. This fact corroborates the results observed in this study. Possibly, the mineral nitrogen present in the T2 and T4 treatments associated with the organic waste decreased the $\mathrm{C} / \mathrm{N}$ ratio and stimulated the degradation of these materials by the actinomycetes, resulting in an increase in the population.

Finally, it is suggested the possibility of using filter cake and poultry litter as a source of nutrients for soybean cultivation, because the application improves the soil properties and does not cause negative changes in the microbial population.

\section{CONCLUSIONS}

The use of organic the poultry litter and sugarcane filter cake in the soybean crop proved to be feasible for the sustainable management of this legume, without negatively influencing germination, nodulation and productivity.

Only the population of actinomycetes was influenced by the application of the poultry litter and sugarcane filter cake in the soil under the conditions of this experiment.

\section{ACKNOWLEDGEMENTS}

The authors thank Unicesumar for providing the infrastructure to carry out this work, the ICETI for the financial contribution and also to thank the Coordination for the Improvement of Higher Education Personnel (CAPES / BRASIL) for granting the scholarship.

\section{REFERENCES}

Adeli, A., Sistani, K.R., Rowe, D.E. and Tewold, H., 2005. Effects of broiler litter on soybean production and soil nitrogen and phosphorus concentrations. Agronomy Journal, 97 (3):14-321. DOI: 10.2134/agronj2005.0314

Boateng, S.A., Zickermann, J. \& Kornahrens, M., 2006. Poultry manure effect on growth and yield of maize. West African Journal of Applied Ecology, 9:1-11. DOI: 10.4314/wajae.v9i1.45682 
Câmara, G.M.S., 2000. Soja: tecnologia da produção II. Gil Miguel de Sousa Câmara (editor), Piracicaba: ESALQ/LPV,

Câmara, G. M. S., 2014. Fixação biológica de nitrogênio em soja. Informações Agronômicas, Piracicaba, $147:$ 1-9.

Canteri, M.G., Althaus, R.A., Virgens Filho, J. S., Giglioti, E. A., Godoy, C. V., 2001. SASM - Agri: Sistema para análise e separação de médias em experimentos agrícolas pelos métodos Scoft - Knott, Tukey e Duncan. Revista Brasileira de Agrocomputação, 1 (2): 18-24.

Castro, S. H., Reis, R. P., Lima, A. L. R., 2006. Custos de produção da soja cultivada sob sistema de plantio direto: estudo de multicasos no oeste da Bahia. Ciência e Agrotecnologia, 30 (06): 1146-1153.

Costa, A. M., 2009. Potencial de recuperação física de um latossolo vermelho, sob pastagem degradada, influenciado pela aplicação de cama de frango. Ciência e Agrotecnologia, 33: 1991-1998.

Departamento de Agricultura dos Estados Unidos - USDA. Retrieved from https://www.fas.usda.gov on 31 st January 2019

De Paula Junior, S. E.M., 2014. Avaliação das alternativas de disposição final do resíduo da produção de frango de corte: cama de frango. Tese (Doutorado). Universidade Federal do Rio de Janeiro.

Fravet, P. R. F., Soares, R. A. B., Lana, R. M. Q., Lana, A. M. Q., Korndorfer, G. H., 2010. Efeito de Doses de torta de filtro e modo de aplicação sobra a produtividade e qualidade tecnológica da soqueira de cana de açúcar. Ciência e Agrotecnologia, 34(3): 618-624.

Ghosh, P. K., 2009. Assessment of nutrient competition and nutrient requirement in soybean/sorghum intercropping system. European Journal of Agronomy, 31(1): 43-50. DOI: 10.1016/j.eja.2009.03.002

González, L. C., De Mello Prado, R., Hernández, A. R., Caione, G., and Selva, E. P., 2014. Uso de torta de filtro enriquecida com fosfato natural e biofertilizantes em Latossolo Vermelho distrófico. Pesquisa Agropecuária Tropical (Agricultural Research in theTropics), 44 (2): 135-141. DOI: 10.1590/S1983-40632014000200001.

Magalhães, L., 2017. Carbono orgânico e atributos físicos do solo após a aplicação de esterco bovino. Dissertação (mestrado) Universidade Estadual Paulista.

Mahajan A., Bhagat R.M., Gupta R.D. 2008. Integrated nutrient management in 860 sustainable rice-wheat cropping system for food security in India. 861 SAARC Journal of Agriculture 6(2): 149-163.

Malavolta, E., 2006. Manual de nutrição mineral de plantas. São Paulo: Agronômica Ceres.

Manteli, C., Rosa M., Stefeni, A. R., Svidzinski, R. S., Schneider, F.L., Barbieri, C. 2019. Calcium and Boron Apply Via Leaf On Reproductive Stages R1 and R3 in Soybean Culture. Australian Journal of Basic and Applied Sciences, 13(1): 23-27. DOI: 10.22587/ajbas.2019.13.1.4

Moreira, F.M.S. and Siqueira, J.O., 2012. Microbiologia e bioquímica do solo. 2. ed. Lavras, Universidade Federal de Lavrasp.

Neves, C.P., Lima, I.T., Dobereiner, J., 1983. Efeito da vinhaça sobre a microflora do solo. Revista Brasileira de Ciências do Solo, 7:131-136.

Nunes Júnior, D., 2005. O insumo torta de filtro. IDEA News, Ribeirão Preto.

Pimentel, D., 2009. Energy inputs in food crop production in developing and developed nations. Energies, 2(1): 1-24. DOI: 10.3390/en20100001

Ribeiro, D. O., 2009. Comparação de adubação química com cama de frango na cultura da soja (Glycine max) em Latossolo vermelho amarelo distrófico no sudoeste goiano. In: Congresso Brasileiro de Soja, 5., Goiânia. Anais... Londrina: EMBRAPA Soja.

Rodrigues, H. J. B., 2011. Variabilidade quantitativa de população microbiana associada às condições microclimáticas observadas em solo de floresta tropical úmida. Revista Brasileira de Meteorologia, 26(4): 629-638.

Ruviaro, C., Dorneles, J.G.L., Silva, A.M., Ben, C.A.V., 2011. Comportamento da soja submetida a diferentes regimes hídricos e viabilidade da irrigação suplementar na região do Vale do Jaguari-RS. Perspectiva, 35:79-90.

Santana, C. T. C., Santi, A., Dallacort, R., Santos, M. L., De Menezes, C. B., 2012. Desempenho de cultivares de alface americana em resposta a diferentes doses de torta de filtro. Revista Ciência Agronômica, 43(1): 22-29.

Santos, T.M.C., Santos, M. A. L., Santos C. G., Santos V. R., Pacheco D. S. 2009. Efeito da fertirrigação com vinhaça nos microrganismos do solo. Revista caatinga, 22(1):155-160.

Staut, L. A., 2009. Adubação foliar com nutrientes na cultura da soja. Embrapa Agropecuária Oeste-Artigo de divulgação na mídia (INFOTECA-E).

Szogi, A. A., Bauer, P. J., Vanotti, E. M. B., 2010. Fertilizer effectiveness of phosphorus recovered from broiler litter. Agronomy Journal, 102(2): 723-727. 